Ethos: Jurnal Penelitian dan Pengabdian kepada Masyarakat, Vol 8, No.2, Juni 2020: 271-275

\title{
Upaya Pencegahan ISPA dan Menekan Penggunaan Kosmetik Berbahaya di DESA KUNANGAN
}

\section{${ }^{1}$ Santi Perawati, ${ }^{2}$ Fidya Rizky Bardani, ${ }^{3}$ Hamidah, ${ }^{4}$ Dewi Sartika Putri, ${ }^{5}$ Maya Gusri Yanti}

\author{
1,2,3,4,5STIKES Harapan Ibu Jambi, Jambi, Jambi, Indonesia \\ email: ${ }^{1}$ santiperawati@gmail.com
}

\begin{abstract}
The highest ranking disease in Kunangan Village, Taman Rajo District, Muaro Jambi District is ARI (Acute Respiratory Infection). Objective: To increase public knowledge about ARI starting from understanding, causes, risk factors, prevention and treatment both conventional and traditional. Method: counseling and distribution of pamphlets, research results: $80 \%$ of 15 respondents have understood the material presented. Furthermore, responding to the issue of dangerous cosmetics circulating in the community thus encouraging the team to conduct counseling. Purpose: To increase public knowledge about what cosmetics are, what are harmful cosmetics ingredients and how to recognize illegal cosmetics. Method: counseling and distribution of pamphlets, research results: $75 \%$ of 86 respondents have understood the material presented.
\end{abstract}

Keywords: ARI, cosmetics, counselling

\begin{abstract}
Abstrak. Penyakit dengan peringkat tertitinggi di Desa Kunangan Kecamatan Taman Rajo Kabupaten Muaro Jambi adalah penyakit ISPA (Infeksi Saluran Pernapasan Akut). Tujuan: Untuk meningkatkan pengetahuan masyarakat mengenai ISPA mulai dari pengertian, penyebab, faktor resiko, pencegahan dan pengobatan baik konvensional maupun tradisional. Metode: penyuluhan dan pembagian pamflet, hasil penelitian: 80\% dari 15 responden telah paham mengenai materi yang disampaikan. Selanjutnya, menanggapi isu kosmetik berbahaya yang beredar di masyarakat sehingga mendorong tim untuk melakukan penyuluhan. Tujuan: Untuk meningkatkan pengetahuan masyarakat mengenai apa itu kosmetika, apa saja bahan berbahaya kosmetika dan cara mengenali kosmetik ilegal. Metode: penyuluhan dan pembagian pamflet, hasil penelitian: $75 \%$ dari 86 responden telah paham mengenai materi yang disampaikan.
\end{abstract}

Kata Kunci: ISPA, kosmetika, penyuluhan 


\section{Pendahuluan}

Hasil survei lapangan tim pengabdian masyarakat menemukan bahwa, berdasarkan data puskesmas pembantu desa kunangan penyakit ISPA (Infeksi Saluran Pernapasan Akut) merupakan penyakit yang sering muncul di desa tersebut dan bertahan pada peringkat satu teratas setiap tahunnya. Tahun 2020 sendiri, hingga bulan februari tercatat se banyak 16 pasien yang menderita ISPA (Infeksi Saluran Pernapasan Akut). Penyakit ISPA merupakan infeksiyang terjadi pada satu atau lebih bagian saluran masuknya udara ke dalam tubuh sehingga menimbulkan pernapasan tidak berfungsi dengan baik. Gangguan tersebut bisa berupa infeksi tenggorokan (laring), infeksi jalur utama udara (trakea) maupun jalur udara yang masuk ke dalam paru-paru (bronkus) yang biasa juga disebut peradangan. (Syamsudin \& Keban, 2013)

Pengamatan lain ditemukan fakta bahwa desa kunangan masuk dalam kawasan industri, banyaknya pabrikpabrik yang beroperasi di sekitar desa menyebabkan polusi udara. Udara semacam ini yang setiap hari dihirup masyarakat desa kunangan dan menjadi faktor pemicu ISPA (Infeksi Saluran Pernapasam Akut). Berkaca dari fakta tersebut, upaya pencegahan terlihat belum diterapkan masyarakat desa, minimnya pengetahuan masyarakat mengenai ISPA (Infeksi Saluran Pernapasan Akut) membuat penyakit ini tidak turun dari peringkat teratas daftar penyakit terbanyak di desa tersebut. Berdasarkan masalah diatas, tim pengabdian mencoba untuk memberikan penyuluhan mengenai penyakit ISPA (Infeksi Saluran Pernapasan Akut) pencegahan dan pengobatan herbal pada masyarakat desa kunangan untuk menuntaskan masalah ISPA yang ada di desa tersebut.
Maraknya isu kosmetika berbahaya menjadi perhatian khusus di kalangan masyarakat, sedangkan kosmetika sendiri merupakan kebutuhan yang cukup penting dalam kehidupan sehari-hari. Tanpa kita sadari kosmetika berbahaya dengan mudah ditemukan disekitar kita. Kosmetika tidak hanya digunakan untuk fungsi estetika, tetapi juga digunakan untuk penyembuhan dan perawatan kulit. Oleh sebab itu pengetahuan mengenai bahan-bahan berbahaya yang ada pada kosmetika seharusnya menjadi hal yang tabu mengingat efek samping mengerikan dapat timbul dari bahan berbahaya kosmetika baik jangka pendek maupun jangka panjang. (Muliyawan dan Suriana, 2013)

Survei yang dilakukan pada pemuda-pemudi desa kunangan, dari 86 responden $87 \%$ pemuda-pemudi menggunakan kosmetik, mulai dari bedak, krim, gel rambut, sabun cuci muka, blush on, lipstik dan lain sebagainya. Berdasarkan hasil observasi dari 86 responden hanya $10 \%$ diantaranya yang mengetahui dengan pasti apa itu kosmetika, apa saja bahan berbahaya kosmetika dan cara mengenali kosmetik ilegal, 90\% sisanya hanya menggunakan kosmetika tanpa mengetahui poin-poin tersebut. Berdasarkan pengamatan diatas, tim pengabdian masyarakat memilih responden pemuda-pemudi desa kunangan dengan membrikan penyuluhan mengenai kosmetika.

\section{Metode}

Kegiatan pengabdian kepada masyarakat ini dilaksanakan tanggal 0522 februari 2020. Lokasi kegiatan ini adalah Desa Kunangan Kecamatan Taman Rajo Kabupaten Muaro Jambi.

\section{Tahap Awal}

Tahapan pengabdian masyarakat ini dimulai dari survei awal berupa wawancara langsung kepada bidan desa 
mengenai penyakit tertinggi di desa kunangan. Selanjutnya dijadwalkan kegiatan musyawarah masyarakat desa bersama tim pengabdi guna merencakan kegiatan penyuluhan ISPA dan Kosmetika di desa kunangan. Selanjutnya tim pengabdi menentukan jadwal penyuluhan dan mempersiapkan media penyuluhan berupa leaflet.

2. Penyuluhan

Pelaksanaan penyuluhan tentang penyakit ISPA (Infeksi Saluran Pernapasan Akut) dilakukan pada saat setelah kegiatan senam rutin di desa kunangan dengan sasaran ibu-ibu dan bapak-bapak. Pelaksanaan penyuluhan Kosmetika dilakukan pada saat perkumpulan pemuda-pemudi desa kunangan dengan sasaran pemudapemudi. Media yang digunakan berupa leaflet yang dibagi-bagikan kepada responden dan disertai dengan pemberian materi secara presentasi.

\section{Tanya Jawab dan Evaluasi}

Setelah pembagian leaflet dan persentasi penyuluhan selanjutnya tim pengabdi membuka sesi tanya jawab kepada bapak-ibu responden penyuluhan ISPA dan pemuda-pemudi responden penyuluhan kosmetika dan ditutup dengan evaluasi dari tim pengabdi untuk melihat peningkatan pengetahuan responden.

\section{Hasil dan Pembahasan}

1. Penyuluhan ISPA (Infeksi Saluran Pernapasan Akut)
Penyuluhan dilakukan pada saat kegiatan senam rutin desa kunangan yang berlokasi di RT.06 yang dihari oleh 15 responden. Capaian penyuluhan ini adalah masyarakat mengerti mengenai penyakit ISPA mulai dari pengertian, penyebab, faktor resiko, pencegahan dan pengobatan baik konvensional maupun tradisional.

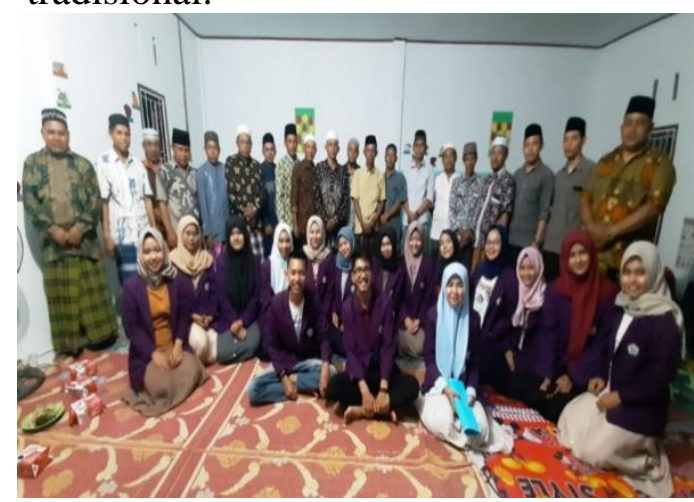

Gambar 1. Musyawarah masyarakat desa di PAUD Al-baraqah Desa Kunangan

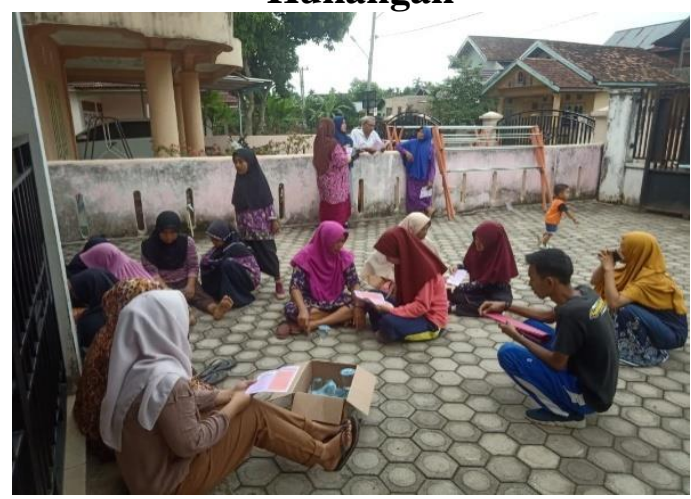

Gambar 3. Penyuluhan ISPA Bersama Bapak-Ibu Desa Kunangan

\begin{tabular}{ccc}
\hline \multirow{2}{*}{$\begin{array}{c}\text { Pengetahu } \\
\text { an }\end{array}$} & $\begin{array}{c}\text { Sebelum } \\
\text { penyuluh } \\
\text { an }\end{array}$ & $\begin{array}{c}\text { Sesudah } \\
\text { penyuluh } \\
\text { an }\end{array}$ \\
\cline { 2 - 3 } & $5 \%$ & $80 \%$ \\
\hline
\end{tabular}

Tabel 1. Hasil tes pengetahuan penyuluhan penyakit ISPA 


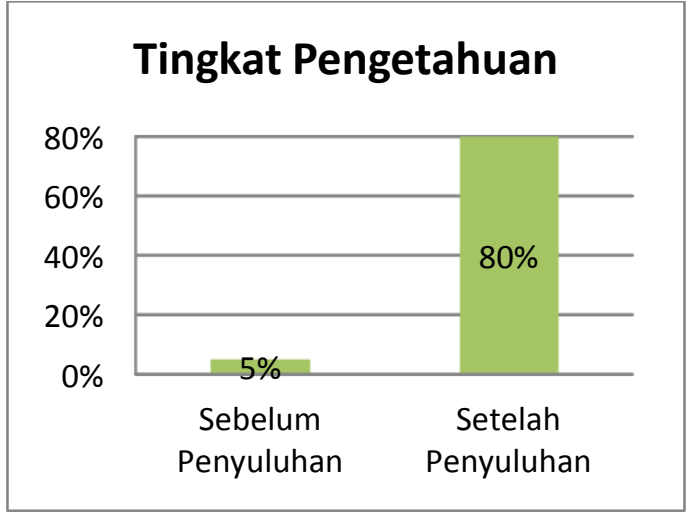

Gambar 3. Grafik hasil penyuluhan ISPA

Berdasarkan grafik di atas dapat terbaca bahwa sebelum dilakukan penyuluhan ISPA terhadap responden, hanya $5 \%$ dari 15 masyarakatyang mengetahui tentang ISPA. Masyarakat mengakui penyakit ISPA sendiri merupakan penyakit yang tidak pernah mereka dengar, setelah diberikan penjelasan oleh tim pengabdi, masyarakat mengaku menyebutnya sebagai penyakit sesak. Setelah dilakukan penyuluhan dan evaluasi, $80 \%$ dari 15 responden telah paham mengenai materi yang disampaikan mulai dari pengertian, penyebab, faktor resiko, pencegahan dan pengobatan baik konvensional maupun tradisional.

2. Penyuluhan Kosmetika

Penyuluhan dilakukan dengan mengumpulkan pemuda-pemudi desa kunangan di salah satu rumah warga tepatnya di RT.05, kegiatan ini dihadiri oleh 86 pemuda-pemudi. Capaian penyuluhan ini adalah pemuda-pemudi mengerti kosmetika mulai dari pengertian kosmetika, apa saja bahan berbahaya kosmetika dan cara mengenali kosmetik ilegal.

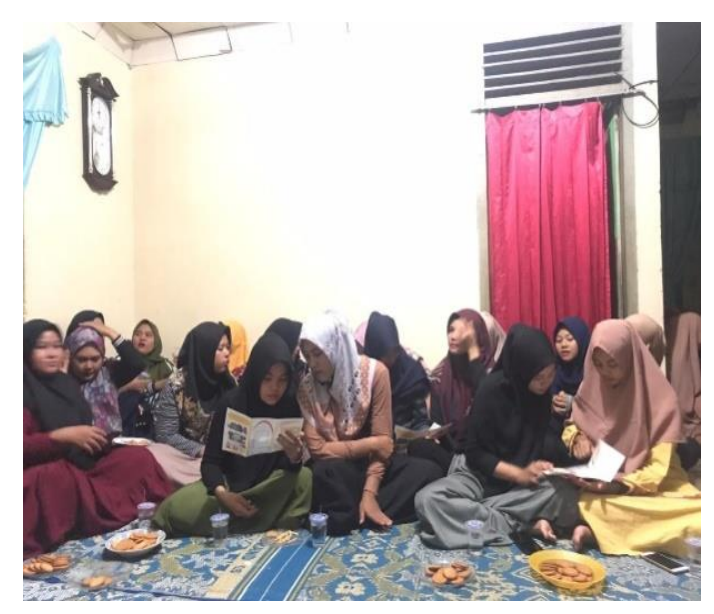

\section{Gambar 2. Penyuluhan Kosmetika Bersama Pemuda-Pemudi Desa Kunangan}

\begin{tabular}{cllr}
\hline \multirow{2}{*}{$\begin{array}{c}\text { Pengetahu } \begin{array}{c}\text { Sebelum } \\
\text { penyuluh } \\
\text { an }\end{array} \\
\text { an }\end{array}$} & $\begin{array}{l}\text { Sesudah } \\
\text { penyuluh } \\
\text { an }\end{array}$ \\
\cline { 2 - 3 } & $\begin{array}{ll}10 \\
\%\end{array}$ & 75 \\
\hline
\end{tabular}

Tabel 2. Hasil tes pengetahuan penyuluhan penyakit ISPA

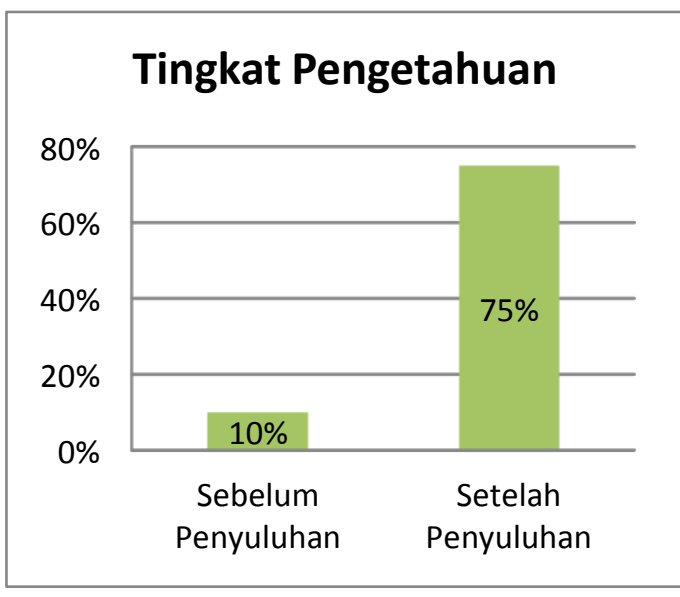

\section{Gambar 5. Grafik hasil penyuluhan} Kosmetika

Berdasarkan grafik di atas dapat terbaca bahwa sebelum dilakukan penyuluhan Kosmetika terhadap responden, hanya $10 \%$ dari 86 responden yang mengetahui dengan pasti mengenai kosmetika. Pemuda-pemudi mengaku hanya menggunakan kosmetika tanpa tahu bahan yang digunakan dan izin edar dari kosmetik yang mereka gunakan. 
Setelah dilakukan penyuluhan dan evaluasi, $75 \%$ dari 86 responden telah paham mengenai materi yang disampaikan mulai dari pengertian kosmetika, apa saja bahan berbahaya kosmetika dan cara mengenali kosmetik ilegal.

\section{Kesimpulan dan Saran}

\section{Kesimpulan}

Kegiatan ini telah meningkatkan pengetahuan masyarakat mengenai Penyakit ISPA, pencegahan dan pengobatannya baik obat konvensional maupun obat tradisional. Selain itu juga telah meningkatkan peningkatan pengetahuan dan kewaspadaan pemudapemudi dalam memilik kosmetik yang baik berdasarkan bahan yang digunakan dan izin edar kosmetik.

\section{Saran}

Diharapkan untuk peserta tim pengabdian selanjutnya agar dapat menggerakkan masyarakat dan memantau keberlanjutan program yang sudah dijalankan guna untuk meningkatkan kesejahteraan masyarakat.

\section{DAFTAR PUSTAKA}

Muliyawan D. dan Suriana N., 2013, A$\mathrm{Z}$ tentang Kosmetika, PT Elex MediaKomputindo, Jakarta: 38-115. Syamsudin, Kehan, S.A. (2013). Buku

Ajar Farmakoterapi Gangguan Saluran Pernapasan. Jakarta: Salemba Medika

Data Puskesmas Pembantu Desa Kunangan Tahun 2020 